\title{
In vitro/ In vivo Electrochemical Detection of Pt(II) Species
}

\author{
Alexander N. Vaneev[a,b]*, Petr V. Gorelkin[a]*, Olga O. Krasnovskaya ${ }^{[a, b]}$, Roman A. Akasov[c,d], \\ Daniil V. Spector[a,b], Elena V. Lopatukhina ${ }^{[a]}$, Roman V. Timoshenko[a], Anastasia S. Garanina ${ }^{[a]}$, \\ Yanjun Zhang[e], Sergey V. Salikhov ${ }^{[a]}$, Christopher R.W. Edwards[f], Natalia L. Klyachko[b], Yasufumi \\ Takahashi[e], Alexander G. Majouga ${ }^{[a]}$, Yuri E. Korchev $[a, e, f]^{*}$ and Alexander S. Erofeev $\left.{ }^{[a, b}\right]^{*}$
}

[a] National University of Science and Technology (MISIS), Leninskiy prospect 4, Moscow 119049, Russia

[b] Lomonosov Moscow State University, Chemistry Department, Leninskie gory 1,3, Moscow, 119991, Russia

[c] Federal Scientific Research Centre "Crystallography and Photonics" of Russian Academy of Sciences, Moscow, 119333 Russia

[d] Sechenov First Moscow State Medical University, Moscow, 119991 Russia

[e] Nano Life Science Institute (WPI-NanoLSI), Kanazawa University, Kakuma-machi, Kanazawa 920-1192, Japan

[f] Imperial College London, Department of Medicine, London, W120NN, United Kingdom

ABSTRACT: The biodistribution of chemotherapy compounds within tumor tissue is one of the main challenges in the development of antineoplastic drugs, and novel techniques for simple, non-expensive, sensitive, and selective detection of various analytes in tumors are of great importance. In this paper we propose the use of platinized carbon nanoelectrodes (PtNE) for electrochemical detection of platinum-based drugs in various biological models, including single cells and tumor spheroids in vitro, and inside solid tumors in vivo. We have demonstrated quantitative direct detection of Pt(II) in breast adenocarcinoma MCF-7 cells treated with cisplatin and cisplatin-based DNP prodrug. To realize the potential of this technique in advanced tumor models, we measured Pt(II) in 3D tumor spheroids in vitro and tumor-bearing mice in vivo. The concentration gradient of Pt (II) species correlated with the distance from the sample surface in MCF-7 tumor spheroids. We then performed detection of $\mathrm{Pt}(\mathrm{II})$ species in tumor-bearing mice treated intravenously with cisplatin and DNP. We found that there was deeper penetration of DNP in comparison to cisplatin. This research demonstrates a novel minimally invasive, real-time electrochemical technique for the study of platinum-based drugs.

\section{KEYWORDS: cisplatin, electrochemical detection, nanopipette, single cell}

Platinum-based drugs remain among the most widely used anticancer drugs, and various approaches to enhancing their target delivery to tumors have been proposed. ${ }^{1-3}$ A simple and quick quantitative assessment of the drug accumulation in tumors in vivo could improve the predictive power of preclinical drug screening. A variety of analytical techniques such as chromatography, ${ }^{4,5}$ spectroscopy, ${ }^{6}$ and voltammetry ${ }^{7,8}$ have been proposed for the detection of platinum-based drugs and their metabolites in biological fluids and tissues. ${ }^{9}$

Atom-based elemental imaging techniques, such as electron microscopy ${ }^{10}$ and X-ray microanalysis, ${ }^{11}$ have been used for mapping the intracellular and intratumoral distribution of cisplatin, and passive drug diffusion through the cellular membrane has been found as the main internalization mechanism. This could be one of the problem in chemoresistant tumors. Laser ablation-inductively coupled plasma-mass spectrometry (LA-ICP-MS) with pixel dimension of 2-10 $\mu \mathrm{m}$ has been used to demonstrate the concentration gradient of cisplatin in tumor spheroids in vitro and the preferential accumulation of cisplatin in necrotic regions of tumors in vivo. ${ }^{12,13}$ Mass cytometry has facilitated the evaluation of Pt levels as low as $10^{5}$ to $10^{6}$ atoms per cell after a single intraperitoneal cisplatin administration using clinically relevant doses in mice xenograft model. ${ }^{14} \mathrm{How}-$ ever, despite the high accuracy, these techniques require a complex sample preparation that often causes significant changes in the drug distribution. ${ }^{15,16}$
Electrochemical detection is a highly sensitive and simple technique that has been successfully used to detect various metabolites in buffers, cells, and tissues. ${ }^{17,18}$ However, the use of electrochemical techniques for platinum-based drug detection is currently limited to buffer solutions and biological fluids. ${ }^{7,8,19}$ Thus, electrodes based on metallothionein and glutathione-stransferase enzymes ${ }^{20}$ and on thionine-modified graphene quantum dots ${ }^{21}$ have been used for the detection of cisplatin in phosphate buffered saline (PBS). A Pt-disk macroelectrode was used to detect carboplatin in cell medium to quantify drug consumption by cancer cells. ${ }^{22}$ However, these sensors are large (in micrometric range), so hardly suitable for detection of cisplatin in single cells or tissues. Therefore, the development of nano-sized low-invasive, selective, and sensitive sensors for in vitro and in vivo real-time experiments is an important challenge.

Nanopipettes have emerged as a promising platform in recent years since they have found many applications in analytical chemistry and can be easily fabricated. ${ }^{23-25}$ Nanopipettes are used for imaging of biological objects with scanning ion-conductance microscopy, ${ }^{26}$ quantitative nanomechanical mapping of cells, ${ }^{27}$ dynamic mapping of extracellular $\mathrm{pH}$ at the singlecell level, ${ }^{28}$ detection of protein ${ }^{29}$ and determination of ROS generation under the influence of novel prospective antitumor drugs. $^{30-34}$ Recently, disk-shaped carbon nanoelectrodes 
A)

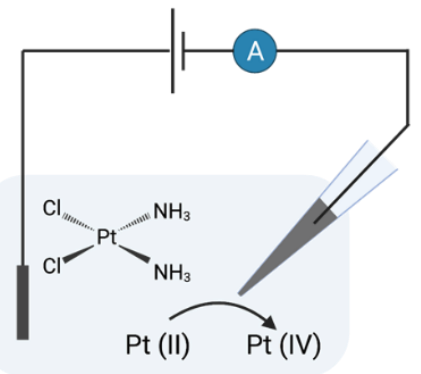

E)

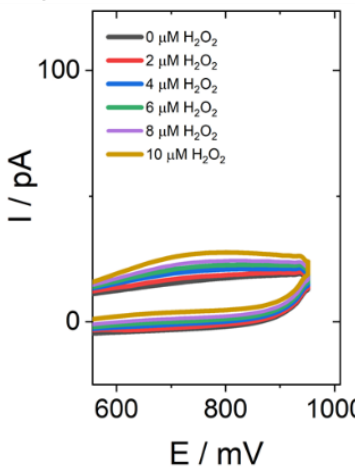

F)

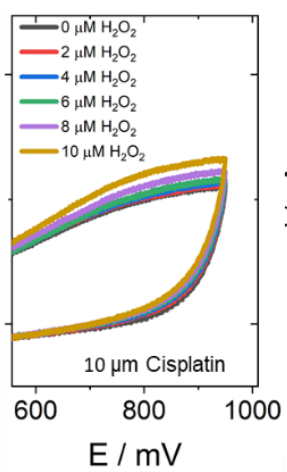

B)

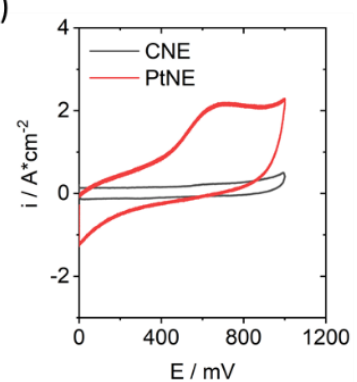

G)

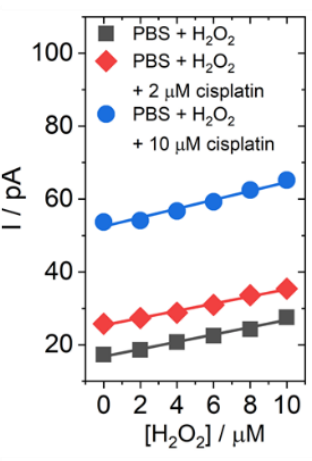

C)

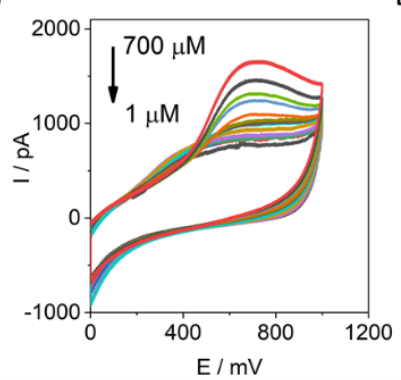

H)

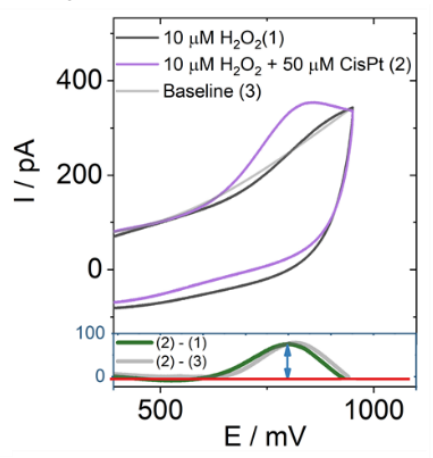

D)

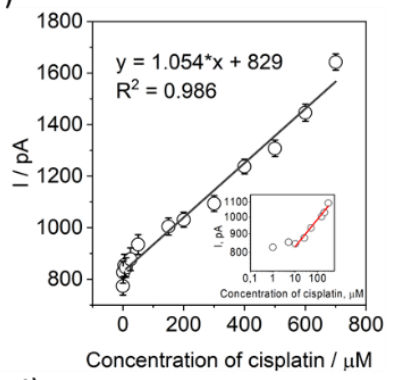

I)

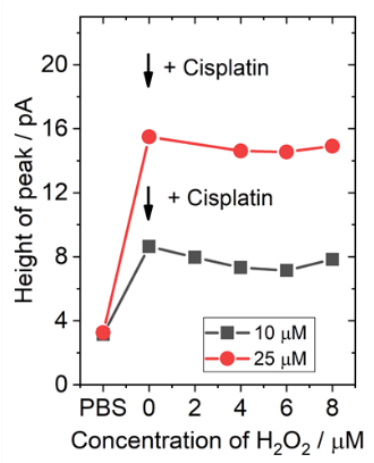

Figure 1. Nanoelectrode preparation and Pt detection. (A)Schematic for the nanoelectrode and the working principle of cisplatin detection (B) CVs in $0.5 \mathrm{mM}$ cisplatin in PBS solution obtained with CNE and PtNE. Scan rate $250 \mathrm{mV} \mathrm{s}^{-1}$. (C) Effect of different concentrations of cisplatin (from bottom to top: 1-700 $\mu \mathrm{M}$ ) on the response of the electrode (D) Calibration curve in PBS at pH 7.4. Scan rate $250 \mathrm{mV} \mathrm{s}^{-1}$. The inset shows an enlarged section of the calibration curve over the range (0-200 $\left.\mu \mathrm{m}\right)(\mathrm{E}) \mathrm{CVs}$ in PBS in different concentrations of $\mathrm{H}_{2} \mathrm{O}_{2}(0-10 \mu \mathrm{M})(\mathrm{F}) \mathrm{CVs}$ in $10 \mu \mathrm{M}$ cisplatin in different concentrations of $\mathrm{H}_{2} \mathrm{O}_{2}(0-10 \mu \mathrm{M})(\mathrm{G})$ Measured current at a potential of $+800 \mathrm{mV}$ in different solutions of hydrogen peroxide $(0-10 \mu \mathrm{M})$ and mixture of hydrogen peroxide and 2 or $10 \mu \mathrm{M}$ cisplatin (H) CVs in $10 \mu \mathrm{M} \mathrm{H}_{2} \mathrm{O}_{2}$ and $10 \mu \mathrm{M} \mathrm{H}_{2} \mathrm{O}_{2}+50 \mu \mathrm{M}$ cisplatin. Baseline was represented as spline line (method 2nd derivative, polynomial order 2) The bottom of the graph shows the subtraction between 2 and 1 (green) and between 2 and baseline (grey). (I) Dependence of height of anodic peak of cisplatin oxidation on $\mathrm{H}_{2} \mathrm{O}_{2}$ concentration.

(CNEs) have been used to determine reactive oxygen/nitrogen species (ROS / RNS), ${ }^{23,35-41}$ oxygen, ${ }^{23} \mathrm{ATP},{ }^{42}$ and catecholamines ${ }^{43}$ inside single cells. Due to their nanometer size, these electrodes can penetrate the cell membrane without destruction of cell integrity ${ }^{44}$ as shown by our previous research on ROS detection. ${ }^{23,40} \mathrm{At}$ the same time, they have the required mechanical properties for penetration into the tumor tissue and subsequent in vivo measurements. ${ }^{38}$

In this work, we have expanded the application of the platinized carbon nanoelectrode (PtNE), providing direct intracellular and intratumoral quantitative electrochemical detection of $\mathrm{Pt}(\mathrm{II})$ species. We have used a cisplatin modified with two naproxen axial ligands (DNP), as a model compound with better intracellular accumulation properties. ${ }^{45}$ This is the first application of a platinized nanoelectrode to assess the accumulation of platinum-based drugs in living systems, including tumor spheroids in vitro and solid tumors in vivo in a real-time manner.

To fabricate the PtNE a glass nanopipette was filled with carbon (Figure S1A, B). Before Pt deposition we controlled the size of CNEs by steady-state voltammetry of $1 \mathrm{mM} \mathrm{FcMeOH}$ solution in PBS (Figure S2). To enhance the adhesion of the platinum a nanocavity etched into the carbon electrode was used. Electrochemical etching was performed by means of cyclic voltammetry (CV) from 0 to $2.2 \mathrm{~V}$ in $0.1 \mathrm{M} \mathrm{KOH}$ and 10 $\mathrm{mM} \mathrm{KCl}$ for typically 15-40 cycles until the formation of nanocavities. (Figure S3A, B) Then platinum was deposited to increase the electrochemical activity of the surface (Figure
S3C). Electrochemical deposition of platinum was achieved by cycling from 0 to $-0.8 \mathrm{~V}$ with a scan rate of $200 \mathrm{mV} \mathrm{s}^{-1}$ in 2 $\mathrm{mM} \mathrm{H} \mathrm{PtCl}_{6}$ solution in $0.1 \mathrm{M}$ hydrochloric acid. To assess the deposition of platinum on the nanoelectrode, SEM microphotographs were obtained (back-scatter detector) (Figure S4). The diameter of the PtNE was about 50-150 nm, and this showed excellent electrochemical performance. We performed a study to investigate the reproducibility of the nanoelectrode fabrication, by preparing several nanopipettes $(\mathrm{N}=5)$ with identical pulling parameters, deposited carbon, and averaged their steady state. This demonstrated that this method of producing PtNEs has a high reproducibility (Figure S3D).

To study the redox behavior of cisplatin at various electrode materials, cyclic voltammograms (CVs) of $0.5 \mathrm{mM}$ cisplatin in PBS were recorded at CNE and PtNE (Figure 1A, B). No clear oxidation peak $\mathrm{E}_{\mathrm{pa}}\left(\mathrm{Pt}^{\mathrm{II}} / \mathrm{Pt}^{\mathrm{IV}}\right)$ was observed at CNE. Cisplatin exhibits a pronounced oxidation peak at potential of $0.65-0.7 \mathrm{~V}$ vs $\mathrm{Ag} / \mathrm{AgCl}$ at PtNE, as shown in Figure 1B. No clear cathodic peak current was observed during the reverse sweep, indicating a chemically irreversible oxidation process $\mathrm{E}_{\mathrm{pa}}\left(\mathrm{Pt}^{\mathrm{II}} / \mathrm{Pt}^{\mathrm{IV}}\right)$. Both anodic currents were stable and retained $>90 \%$ of their constant values after 2 weeks.

To ensure the reliability of the proposed method for detecting cisplatin in a living system, calibration of PtNE with cisplatin solutions was performed. CVs were obtained in solutions of cisplatin and yielded a linear calibration curve $(1-700 \mu \mathrm{M})($ Figure 1C, D). The platinum deposited on the CNE in the process 
A)

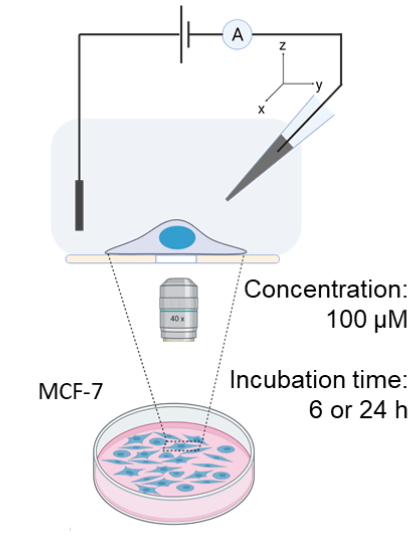

B)

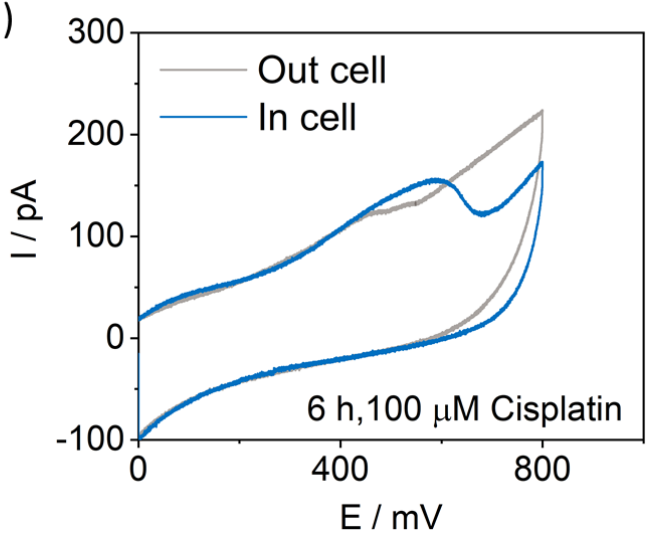

C)

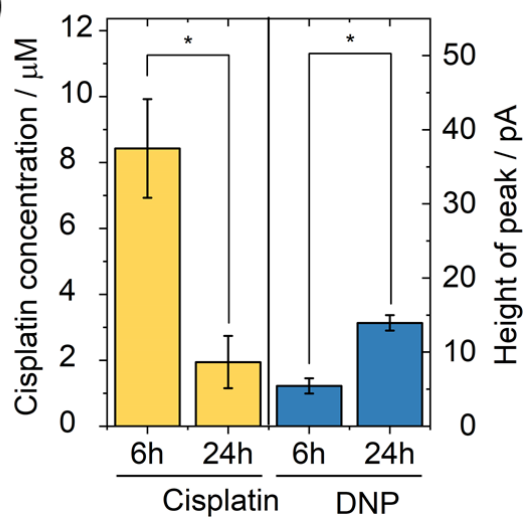

Figure 2. Electrochemical detection cisplatin in MCF-7 cells. (A) Schematic the working principle of cisplatin detection in single cells (B) CVs measuring in and out cells. Scan rate $250 \mathrm{mV} \mathrm{s}^{-1}$. (C) Comparison of height of anodic peak obtained from linear sweep voltammetry proportional to the concentration of Pt(II) inside cells incubated with cisplatin and DNP after $6 \mathrm{~h}$ or $24 \mathrm{~h} .(\mathrm{N}=5)$. * $-\mathrm{p}$ $<0.05$ (ANOVA).

of fabrication can increase the sensitivity of the nanoelectrode several fold but the size of PtNE increases when a large amount of platinum is deposited. A large PtNE can damage the cell, which is undesirable. The resulting minimal detection range was $1-10 \mu \mathrm{M}$ which suffices for tracking drug metabolism both in individual cells and spheroids.

To clarify the oxidation process of the cisplatin, the effect of scan rate $(v)$ ranging from 150 to $1500 \mathrm{mV} \mathrm{s}^{-1}$ on the electrode response was investigated. Increasing the scan rate enhances the peak intensities and shifts the peak potential positively, which reveals the irreversibility of the electrode process. The linear relationship between peak current and the square root of the scan rate indicates that the cisplatin oxidation follows a diffusional process. (Figure S3 A,B)

It is well known that $\mathrm{pH}$ values vary in both cells and tumors ${ }^{46}$, so we assessed the electrochemical behavior of cisplatin under $\mathrm{pH} 2.9-10$ because the oxidation peak $\mathrm{E}_{\mathrm{pa}}\left(\mathrm{Pt}^{\mathrm{II}} / \mathrm{Pt}^{\mathrm{IV}}\right)$ is shifted in different $\mathrm{pH}$ conditions. ${ }^{47}$ The voltammograms of 0.1 M PBS containing $0.1 \mathrm{M} \mathrm{KCl}$ and $0.5 \mathrm{mM}$ cisplatin are presented in Figure S5C, D. We found that by decreasing the $\mathrm{pH}$ the maximum peak current of the oxidation peak $\mathrm{Pt}(\mathrm{II}) / \mathrm{Pt}(\mathrm{IV})$ was shifted positively, revealing that the oxidation of cisplatin is $\mathrm{pH}$-dependent process. In the range $\mathrm{pH}$ 6.5-7.5 peak $\mathrm{E}_{\mathrm{pa}}\left(\mathrm{Pt}^{\mathrm{II}} / \mathrm{Pt}^{\mathrm{IV}}\right)$ was shifted, but height of the anodic oxidative peak was not changed.

We recorded CVs of cisplatin in the presence of hydrogen peroxide in in vitro/in vivo experiments because cisplatin induces ROS generation on cells. CVs were recorded in cisplatin solutions in the presence of hydrogen peroxide at physiological concentration $(0-10 \mu \mathrm{M})$. PtNE enabled the detection of hydrogen peroxide, as shown by the current being increased when this was added (Figure 1E,S6). In $10 \mu \mathrm{M}$ cisplatin current at the range $200-800 \mathrm{mV}$ vs $\mathrm{Ag} / \mathrm{AgCl}$ was increased after increasing hydrogen peroxide concentrations (Figure 1F). The slope of the dependence of the current at +800 $\mathrm{mV}$ on the concentration of added hydrogen peroxide was the same in solutions of cisplatin at different concentrations (Figure $1 \mathrm{G})$. However, we observed an anodic peak of cisplatin. To determine the height of the anodic peak, the baseline was calculated. ${ }^{19}$ We used the 2 nd derivative method with curve of polynomial order 2 (Figure 1H). Baseline matched with CV of
$10 \mu \mathrm{M}$ hydrogen peroxide. It was shown that with an increase in hydrogen peroxide concentration, the background current over the range $200-800 \mathrm{mV}$ vs. $\mathrm{Ag} / \mathrm{AgCl}$ increased, but the height of anodic oxidative peak $\mathrm{Pt}(\mathrm{II}) / \mathrm{Pt}(\mathrm{IV})$ did not change (Figure 1I). Therefore, the content of hydrogen peroxide does not affect the detection of $\mathrm{Pt}(\mathrm{II})$ in the samples.

To characterize and compare intracellular cisplatin concentrations in human breast cancer MCF-7 cells, we incubated them with $100 \mu \mathrm{M}$ cisplatin for 6 and $24 \mathrm{~h}$ (Figure 2A). A few single cells were then penetrated by the PtNE, and $\mathrm{CV}$ s were recorded both in cytoplasm and outer medium (Figure 2B). The height of the oxidative peak $\mathrm{Pt}(\mathrm{II}) / \mathrm{Pt}(\mathrm{IV})$ was measured, which was then normalized to the electrode size measured using $1 \mathrm{mM}$ $\mathrm{FcMeOH}$. After $6 \mathrm{~h}$ of incubation a reproducible oxidation peak
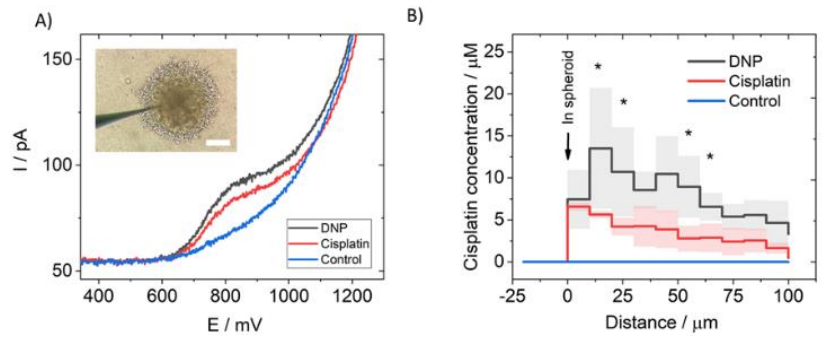

Figure 3. Electrochemical detection cisplatin in MCF-7 spheroids. (A) Linear sweep voltammetry of the DNP and cisplatin after incubation of MCF-7 spheroids. (B) Comparison of height of anodic peak obtained from linear sweep voltammetry proportional to the concentration of $\mathrm{Pt}(\mathrm{II})$ inside spheroids incubated with cisplatin and DNP after 2 h. ${ }^{*}-\mathrm{p}<0.05$ (ANOVA).

of cisplatin was detected, and average cisplatin concentrations in MCF-7 cells were determined using a calibration curve. It should be noted that the peak was shifted to the left (50-75 mV), when compared with the measurements carried out in the solution. This could be explained, firstly, that we were using a different measurement medium as compared to the buffer solution, and secondly, there was a change in the environment of $\mathrm{Pt}(\mathrm{II})$ due to cellular metabolism of the drug. After $24 \mathrm{~h}$ incubation the cisplatin concentration in the cells decreased. A highly 
lipophilic DNP prodrug was used here as an alternative to the normal cisplatin-based compound with improved accumulation in cells. Previously, we have unambiguously proved by X-ray near-edge adsorption spectroscopy (XANES) using drug-preincubated tumor cells that DNP is a prodrug that enters the cell as $\mathrm{Pt}(\mathrm{IV})$, and then slowly releases cisplatin. ${ }^{48}$ In the current research, MCF-7 cells were incubated with $5 \mu \mathrm{M}$ DNP for 6 and $24 \mathrm{~h}$. After $24 \mathrm{~h}$ of incubation with DNP we observed an increase of the anodic peak $\mathrm{E}_{\mathrm{pa}}\left(\mathrm{Pt}^{\mathrm{II}} / \mathrm{Pt}^{\mathrm{IV}}\right)$ height due to accumulation of DNP and slow release of cisplatin from DNP. Despite the fact that we used a concentration 20 times less than that of cisplatin, the detected content of cisplatin was comparable in the two cases. (Figure 2C).

The development of 3D biological models, including tumor spheroids, has opened the possibility to reproduce some conditions of in vivo tumors. Limited diffusion of drugs and gradients of oxygen and nutrients are an important part of the spheroids, which brings them closer to a tumor model in vivo. Here we measured the cisplatin concentration at different depths of the MCF-7-based tumor spheroid after $6 \mathrm{~h}$ incubation with $100 \mu \mathrm{M}$ cisplatin or DNP. For this, PtNE was inserted into a spheroid, and CVs were recorded at each $5 \mu \mathrm{m}$ step. The resulting voltammograms (Figure 3A) showed the presence of $\mathrm{Pt}(\mathrm{II})$ in cisplatin-preincubated MCF-7 spheroids, as well as in DNPpreincubated spheroids. Statistically significant anodic peaks were obtained using one nanoelectrode inside 3 spheroids (Figure S7, S8, S9). More of the lipophilic prodrug DNP accumulated inside the spheroids in comparison with the less lipophilic cisplatin. (Figure 3B). We found that the highest cisplatin and DNP concentrations were detected in the outer layer of spheroids, while the drug amount decreased when approaching the spheroid core. This agrees with previously published data obtained using elemental imaging analysis ${ }^{49}$ and LA-ICP-MS ${ }^{13}$ for cisplatin and cisplatin-based compounds in spheroids.

After validation of the technique using tumor spheroids, realtime measurements in vivo were performed using an EMT6 mammary carcinoma mice model. All animal experiments were performed in accordance with European and Russian national guidelines for animal experimentation, and animal experiments were approved by the local animal and ethics review committee of the FSBSI "N.N. Blokhin Russian Cancer Research Center" (protocol O4P-29.09.2021).
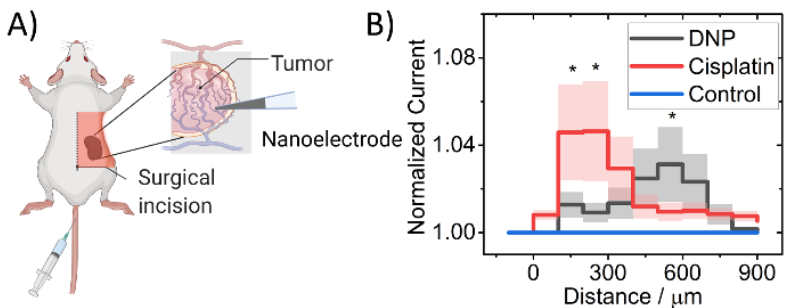

Figure 4. Detection of cisplatin in tumor-bearing mice. (A) Experimental scheme for the detection of cisplatin (B) Normalized current depending on the distance from the EMT6 tumor surface over 6 hours. Current was directly proportional to $\mathrm{Pt}(\mathrm{II})$ concentration. The standard error is indicated by a colored background. ${ }^{*}$ - $\mathrm{p}<0.05$ (ANOVA).

We treated mice intravenously with $2 \mathrm{mg} \mathrm{kg}^{-1}$ of cisplatin or DNP for $24 \mathrm{~h}$. The administration of PBS was used as a control. For intratumoral measurements, mice were treated as described previously. ${ }^{50}$ Briefly, a longitudinal incision along the spine was made, and a flap of skin removed. The tumor was then washed with PBS, and measurements performed with an electrode carefully inserted into the tumor at an angle of 45 degrees. CVs inside the tumor at different depths up to $800 \mu \mathrm{m}$ with a step of 100 micrometers were registered. An anodic oxidation peak $\mathrm{E}_{\mathrm{pa}}\left(\mathrm{Pt}^{\mathrm{II}} / \mathrm{Pt}^{\mathrm{IV}}\right)$ was observed inside the tumors of cisplatintreated mice (Figure 4A,B). It is important to point out that the peak value varied at different depths, indicating that there was a change in the Pt (II) concentrations inside the tumor. In the control tumors no oxidation peak was observed. It is interesting that in DNP-treated tumors the penetration depth was higher in comparison with cisplatin. This correlates with better accumulation of DNP in single cells and spheroids in comparison with cisplatin as described above.

We have detailed a novel method for the intracellular detection of $\mathrm{Pt}(\mathrm{II})$ species. This minimally invasive technique allows the real-time electrochemical detection of $\mathrm{Pt}(\mathrm{II})$ in various tumor models, including single cells and tumor spheroids in vitro and tumors in vivo. We performed intravital detection of $\mathrm{Pt}(\mathrm{II})$ species in tumor-bearing mice treated intravenously with cisplatin or DNP; deeper penetration of DNP in comparison to cisplatin was demonstrated. This research demonstrates a novel low-invasive real-time electrochemical technique which could be used to enhance our understanding of the biology of platinum-based drugs and could thus help in improving their efficacy.

\section{ASSOCIATED CONTENT}

\section{Supporting Information}

The Supporting Information is available free of charge on the ACS Publications website.

\section{AUTHOR INFORMATION}

\section{Corresponding Author \\ *e-mail: vaneev.aleksandr@gmail.com (A.N. Vaneev) \\ *e-mail: peter.gorelkin@gmail.com (P.V. Gorelkin) \\ *e-mail: y.korchev@ic.ac.uk (Y.K. Korchev) \\ *e-mail: erofeev@polly.phys.msu.ru (A. S. Erofeev )}

\section{Notes}

The authors declare the following competing financial interest(s): P.G., Y.K., C. R.W. E. and A.E. are shareholders in ICAPPIC Ltd, a company commercializing nanopipette-based instrumentation.

\section{ACKNOWLEDGMENT}

Development of the nanoelectrodes and biological model was supported by the Ministry of Science and Higher Education within the framework of the Implementation Program Priority 2030. Electrochemical experiments were supported by World Premier International Research Center Initiative (WPI) from MEXT, Japan.; a Grant-in-Aid for Scientific Research (A) (19H00993), a Grant-in-Aid for Scientific Research (B) (20H02582) from the Japan Society for the Promotion of Science (JSPS).

\section{REFERENCES}

(1) Rottenberg, S.; Disler, C.; Perego, P. The Rediscovery of Platinum-Based Cancer Therapy. Nat. Rev. Cancer 2021, 21 (1), 37-50. https://doi.org/10.1038/s41568-020-00308-y.

(2) Spector, D.; Krasnovskaya, O.; Pavlov, K.; Erofeev, A.; Gorelkin, 
P.; Beloglazkina, E.; Majouga, A. Pt(IV) Prodrugs with NSAIDs as Axial Ligands. Int. J. Mol. Sci. 2021, Vol. 22, Page 38172021 , 22 (8), 3817. https://doi.org/10.3390/IJMS22083817.

(3) Johnstone, T. C.; Suntharalingam, K.; Lippard, S. J. The Next Generation of Platinum Drugs: Targeted Pt(II) Agents, Nanoparticle Delivery, and Pt(IV) Prodrugs. Chem. Rev. 2016, $116 \quad$ (5), 3436-3486. https://doi.org/10.1021/ACS.CHEMREV.5B00597.

(4) Vidmar, J.; Martinčič, A.; Milačič, R.; Ščančar, J. Speciation of Cisplatin in Environmental Water Samples by Hydrophilic Interaction Liquid Chromatography Coupled to Inductively Coupled Plasma Mass Spectrometry. Talanta 2015. https://doi.org/10.1016/j.talanta.2015.02.008.

(5) Zachariadis, G. A.; Misopoulou, O. E. Determination of Cisplatin and Carboplatin Anticancer Drugs by NonSuppressed Ion Chromatography with an Inductively Coupled Plasma Atomic Emission Detector. Anal. Lett. 2018, 51 (7), 1060-1070. https://doi.org/10.1080/00032719.2017.1366498.

Basotra, M.; Singh, S. K.; Gulati, M. Development and Validation of a Simple and Sensitive Spectrometric Method for Estimation of Cisplatin Hydrochloride in Tablet Dosage Forms: Application to Dissolution Studies. ISRN Anal. Chem. 2013, 2013 (Ii), 1-8. https://doi.org/10.1155/2013/936254. Materon, E. M.; Wong, A.; Klein, S. I.; Liu, J.; Sotomayor, M. D. P. T. Multi-Walled Carbon Nanotubes Modified ScreenPrinted Electrodes for Cisplatin Detection. Electrochim. Acta 2015. https://doi.org/10.1016/j.electacta.2015.01.184.

(8) Ye, L.; Xiang, M.; Lu, Y.; Gao, Y.; Pang, P. Electrochemical Determination of Cisplatin in Serum at Graphene Oxide/Multi-Walled Carbon Nanotubes Modified Glassy Carbon Electrode. Int. J. Electrochem. Sci. 2014, 9 (3), 15371546.

(9) Bosch, M. E.; Sánchez, A. J. R.; Rojas, F. S.; Ojeda, C. B. Analytical Methodologies for the Determination of Cisplatin. Journal of Pharmaceutical and Biomedical Analysis. Elsevier July 15, 2008, pp 451-459. https://doi.org/10.1016/j.jpba.2008.01.047.

(10) Beretta, G. L.; Righetti, S. C.; Lombardi, L.; Zunino, F.; Perego, P. Electron Microscopy Analysis of Early Localization of Cisplatin in Ovarian Carcinoma Cells. Ultrastruct. Pathol. 2002, $\quad 26 \quad$ (5), 331-334. https://doi.org/10.1080/01913120290104610.

(11) Laforce, B.; Carlier, C.; Vekemans, B.; Villanova, J.; Tucoulou, R.; Ceelen, W.; Vincze, L. Assessment of Ovarian Cancer Tumors Treated with Intraperitoneal Cisplatin Therapy by Nanoscopic X-Ray Fluorescence Imaging. Sci. Reports 201661 2016, 6 (1), 1-8. https://doi.org/10.1038/srep29999.

(12) Theiner, S.; Schweikert, A.; Haberler, C.; Peyrl, A.; Koellensperger, G. Laser Ablation-ICP-TOFMS Imaging of Germ Cell Tumors of Patients Undergoing Platinum-Based Chemotherapy. Metallomics 2020, 12 (8), 1246-1252. https://doi.org/10.1039/D0MT00080A.

(13) Marković, S.; Uršič, K.; Cemazar, M.; Sersa, G.; Starešinič, B.; Milačič, R.; Ščančar, J. High Spatial Resolution Imaging of Cisplatin and Texas Red Cisplatin in Tumour Spheroids Using Laser Ablation Isotope Dilution Inductively Coupled Plasma Mass Spectrometry and Confocal Fluorescence Microscopy. Anal. Chim. Acta 2021, 1162, 338424 https://doi.org/10.1016/J.ACA.2021.338424.

(14) Chang, Q.; Ornatsky, O. I.; Koch, C. J.; Chaudary, N.; MarieEgyptienne, D. T.; Hill, R. P.; Tanner, S. D.; Hedley, D. W. SingleCell Measurement of the Uptake, Intratumoral Distribution and Cell Cycle Effects of Cisplatin Using Mass Cytometry. Int. J. Cancer 2015, 136 (5), 1202-1209. https://doi.org/10.1002/ijc.29074

(15) Bischoff, K.; Lamm, C.; Erb, H. N.; Hillebrandt, J. R. The Effects of Formalin Fixation and Tissue Embedding of Bovine Liver on Copper, Iron, and Zinc Analysis. J. Vet. Diagnostic Investig. 2008, $20 \quad$ (2), 220-224. https://doi.org/10.1177/104063870802000213.

(16) McCormack, M. A.; Jackson, B. P.; Dutton, J. Effects of Formalin Fixation on Trace Element Concentrations in Bottlenose Dolphin ( Tursiops Truncatus ) Tissues. Environ. Toxicol.
Chem. 2020, $39 \quad$ (6), 1149-1164. https://doi.org/10.1002/etc.4709.

Gupta, V. K.; Jain, R.; Radhapyari, K.; Jadon, N.; Agarwal, S. Voltammetric Techniques for the Assay of PharmaceuticalsA Review. Anal. Biochem. 2011, 408 (2), 179-196. https://doi.org/10.1016/j.ab.2010.09.027.

(18) Ogata, G.; Ishii, Y.; Asai, K.; Sano, Y.; Nin, F.; Yoshida, T. Higuchi, T.; Sawamura, S.; Ota, T.; Hori, K.; Maeda, K.; Komune, S.; Doi, K.; Takai, M.; Findlay, I.; Kusuhara, H.; Einaga, Y.; Hibino, H. A Microsensing System for the in Vivo Real-Time Detection of Local Drug Kinetics. Nat. Biomed. Eng. 2017, 1 (8), 654-666. https://doi.org/10.1038/s41551-017-0118-5. Petrlova, J.; Potesil, D.; Zehnalek, J.; Sures, B.; Adam, V.; Trnkova, L.; Kizek, R. Cisplatin Electrochemical Biosensor. Electrochim. Acta 2006, 51 (24), 5169-5173. https://doi.org/10.1016/j.electacta.2006.03.077.

(20) Materon, E. M.; Jimmy Huang, P. J.; Wong, A.; Pupim Ferreira, A. A.; Sotomayor, M. D. P. T.; Liu, J. Glutathione-s-Transferase Modified Electrodes for Detecting Anticancer Drugs. Biosens. Bioelectron. 2014, 58, 232-236. https://doi.org/10.1016/j.bios.2014.02.070.

(21) Gholivand, M. B.; Ahmadi, E.; Mavaei, M. A Novel Voltammetric Sensor Based on Graphene Quantum Dots-Thionine/NanoPorous Glassy Carbon Electrode for Detection of Cisplatin as an Anti-Cancer Drug. Sensors Actuators, B Chem. 2019, 299, 126975. https://doi.org/10.1016/j.snb.2019.126975.

(22) Luu, H. T. Le; Nachtigal, M. W.; Kuss, S. Electrochemical Characterization of Carboplatin at Unmodified Platinum Electrodes and Its Application to Drug Consumption Studies in Ovarian Cancer Cells. J. Electroanal. Chem. 2020, 872, 114253. https://doi.org/10.1016/j.jelechem.2020.114253.

(23) Actis, P.; Tokar, S.; Clausmeyer, J.; Babakinejad, B.; Mikhaleva, S.; Cornut, R.; Takahashi, Y.; López Córdoba, A.; Novak, P.; Shevchuck, A. I.; López Córdoba, A.; Novak, P.; Shevchuck, A. I.; Dougan, J. A.; Kazarian, S. G.; Gorelkin, P. V.; Erofeev, A. S.; Yaminsky, I. V.; Unwin, P. R.; Schuhmann, W.; Klenerman, D.; Rusakov, D. A.; Sviderskaya, E. V.; Korchev, Y. E. Electrochemical Nanoprobes for Single-Cell Analysis. ACS $\begin{array}{llll}\text { Nano } & \mathbf{2 0 1 4}, & 8 & \text { (1), }\end{array}$ https://doi.org/10.1021/nn405612q.

(24) Yu, R. J.; Ying, Y. L.; Gao, R.; Long, Y. T. Confined Nanopipette Sensing: From Single Molecules, Single Nanoparticles, to Single Cells. Angew. Chemie - Int. Ed. 2019, 58 (12), 37063714. https://doi.org/10.1002/anie.201803229.

(25) Hu, K.; Nguyen, T. D. K.; Rabasco, S.; Oomen, P. E.; Ewing, A. G. Chemical Analysis of Single Cells and Organelles. Anal. Chem 2021, 93 (1), 41-71. https://doi.org/10.1021/acs.analchem.0c04361.

(26) Novak, P.; Li, C.; Shevchuk, A. I.; Stepanyan, R.; Caldwell, M.; Hughes, S.; Smart, T. G.; Gorelik, J.; Ostanin, V. P.; Lab, M. J.; Moss, G. W. J.; Frolenkov, G. I.; Klenerman, D.; Korchev, Y. E. Nanoscale Live-Cell Imaging Using Hopping Probe Ion Conductance Microscopy. Nat. Methods 2009, 6 (4), 279-281. https://doi.org/10.1038/nmeth.1306

(27) Kolmogorov, V. S.; Erofeev, A. S.; Woodcock, E.; Efremov, Y. M.; Iakovlev, A. P.; Savin, N. A.; Alova, A. V.; Lavrushkina, S. V.; Kireev, I. I.; Prelovskaya, A. O.; Sviderskaya, E. V.; Scaini, D.; Klyachko, N. L.; Timashev, P. S.; Takahashi, Y.; Salikhov, S. V.; Parkhomenko, Y. N.; Majouga, A. G.; Edwards, C. R. W.; Novak, P.; Korchev, Y. E.; Gorelkin, P. V. Mapping Mechanical Properties of Living Cells at Nanoscale Using Intrinsic Nanopipette-Sample Force Interactions. Nanoscale 2021, 13 (13), 6558-6568. https://doi.org/10.1039/D0NR08349F.

(28) Zhang, Y.; Takahashi, Y.; Hong, S. P.; Liu, F.; Bednarska, J.; Goff P. S.; Novak, P.; Shevchuk, A.; Gopal, S.; Barozzi, I.; Magnani, L. Sakai, H.; Suguru, Y.; Fujii, T.; Erofeev, A.; Gorelkin, P.; Majouga, A.; Weiss, D. J.; Edwards, C.; Ivanov, A. P.; Klenerman, D.; Sviderskaya, E. V.; Edel, J. B.; Korchev, Y. High-Resolution Label-Free 3D Mapping of Extracellular PH of Single Living Cells. Nat. Commun. 2019, 10 (1), 5610 https://doi.org/10.1038/s41467-019-13535-1.

(29) Ren, R.; Wang, X.; Cai, S.; Zhang, Y.; Korchev, Y.; Ivanov, A. P.; Edel, J. B. Selective Sensing of Proteins Using Aptamer Functionalized Nanopore Extended Field-Effect Transistors. 
Small Methods 2020, $2000356 \quad$ (11), 2000356. https://doi.org/10.1002/smtd.202000356.

(30) Krasnovskaya, O. O.; Guk, D. A.; Naumov, A. E.; Nikitina, V. N.; Semkina, A. S.; Vlasova, K. Y.; Pokrovsky, V.; Ryabaya, O. 0.; Karshieva, S. S.; Skvortsov, D. A.; Zhirkina, I. V.; Shafikov, R. R.; Gorelkin, P. V.; Vaneev, A. N.; Erofeev, A. S.; Mazur, D. M.; Tafeenko, V. A.; Pergushov, V. I.; Melnikov, M. Y.; Soldatov, M. A.; Shapovalov, V. V.; Soldatov, A. V.; Akasov, R. A.; Gerasimov, V. M.; Sakharov, D. A.; Moiseeva, A. A.; Zyk, N. V.; Beloglazkina, E. K.; Majouga, A. G. Novel Copper-Containing Cytotoxic Agents Based on 2-Thioxoimidazolones. J. Med. Chem. 2020 , 63 (21),

https://doi.org/10.1021/acs.jmedchem.0c01196.

(31) Yamansarov, E. Y.; Lopatukhina, E. V.; Evteev, S. A.; Skvortsov, D. A.; Lopukhov, A. V.; Kovalev, S. V.; Vaneev, A. N.; Shkil', D. O.; Akasov, R. A.; Lobov, A. N.; Naumenko, V. A.; Pavlova, E. N.; Ryabaya, O. O.; Burenina, O. Y.; Ivanenkov, Y. A.; Klyachko, N. L.; Erofeev, A. S.; Gorelkin, P. V.; Beloglazkina, E. K.; Majouga, A. G. Discovery of Bivalent GalNAc-Conjugated Betulin as a Potent ASGPR-Directed Agent against Hepatocellular Carcinoma. Bioconjug. Chem. 2021 acs.bioconjchem.1c00042.

https://doi.org/10.1021/acs.bioconjchem.1c00042.

(32) Petrov, R. A.; Mefedova, S. R.; Yamansarov, E. Y.; Maklakova, S. Y.; Grishin, D. A.; Lopatukhina, E. V; Burenina, O. Y.; Lopukhov, A. V; Kovalev, S. V; Timchenko, Y. V; Ondar, E. E.; Ivanenkov, Y. A.; Evteev, S. A.; Vaneev, A. N.; Timoshenko, R. V.; Klyachko, N. L.; Erofeev, A. S.; Gorelkin, P. V.; Beloglazkina, E. K.; Majouga, A. G. New Small-Molecule Glycoconjugates of Docetaxel and GalNAc for Targeted Delivery to Hepatocellular Carcinoma. Mol. Pharm. 2021, 18 (1), 461-468. https://doi.org/10.1021/acs.molpharmaceut.0c00980.

(33) Guk, D. A.; Krasnovskaya, O. O.; Moiseeva, A. A.; Tafeenko, V. A.; Ul'yanovskii, N. V.; Kosyakov, D. S.; Pergushov, V. I.; Ya. Melnikov, M.; Zyk, N. V.; Skvortsov, D. A.; Lopatukhina, E. V.; Vaneev, A. N.; Gorelkin, P. V.; Erofeev, A. S.; Majouga, A. G.; Beloglazkina, E. K. New Fe-Cu Bimetallic Coordination Compounds Based on $\omega$-Ferrocene Carboxylic Acids and 2Thioimidazol-4-Ones: Structural, Mechanistic and Biological Studies. Inorg. Chem. Front. 2021 https://doi.org/10.1039/D1QI00714A.

(34) Akasov, R. A.; Sholina, N. V.; Khochenkov, D. A.; Alova, A. V.; Gorelkin, P. V.; Erofeev, A. S.; Generalova, A. N.; Khaydukov, E. V. Photodynamic Therapy of Melanoma by Blue-Light Photoactivation of Flavin Mononucleotide. Sci. Rep. 2019, 9 (1), 9679. https://doi.org/10.1038/s41598-019-46115-w.

(35) Zhang, X. W.; Oleinick, A.; Jiang, H.; Liao, Q. L.; Qiu, Q. F.; Svir, I.; Liu, Y. L.; Amatore, C.; Huang, W. H. Electrochemical Monitoring of ROS/RNS Homeostasis Within Individual Phagolysosomes Inside Single Macrophages. Angew. Chemie $\begin{array}{lllll}\text { Int. } \quad \text { Ed. } & \mathbf{2 0 1 9} & 131 & \text { (23), } & \text { 7835-7838. }\end{array}$ https://doi.org/10.1002/anie.201902734.

(36) Wang, Y.; Noël, J.-M.; Velmurugan, J.; Nogala, W.; Mirkin, M. V.; Lu, C.; Collignon, M. G.; Lemaître, F.; Amatore, C.; Noel, J.-M. Velmurugan, J.; Nogala, W.; Mirkin, M. V.; Lu, C.; Guille Collignon, M.; Lemaitre, F.; Amatore, C. Nanoelectrodes for Determination of Reactive Oxygen and Nitrogen Species inside Murine Macrophages. Proc. Natl. Acad. Sci. 2012, 109 (29),

11534-11539. https://doi.org/10.1073/pnas.1201552109.

(37) Hu, K.; Li, Y.; Rotenberg, S. A.; Amatore, C.; Mirkin, M. V. Electrochemical Measurements of Reactive Oxygen and Nitrogen Species inside Single Phagolysosomes of Living Macrophages. J. Am. Chem. Soc. 2019, 141 (11), 4564-4568. https://doi.org/10.1021/jacs.9b01217.

(38) Vaneev, A. N.; Gorelkin, P. V.; Garanina, A. S.; Lopatukhina, H. V.; Vodopyanov, S. S.; Alova, A. V.; Ryabaya, O. O.; Akasov, R. A.; Zhang, Y.; Novak, P.; Salikhov, S. V.; Abakumov, M. A. Takahashi, Y.; Edwards, C. R. W.; Klyachko, N. L.; Majouga, A. G.; Korchev, Y. E.; Erofeev, A. S. In Vitro and In Vivo
Electrochemical Measurement of Reactive Oxygen Species After Treatment with Anticancer Drugs. Anal. Chem. 2020, 92 (12), https://doi.org/10.1021/acs.analchem.0c01256.

(39) Li, Y.; Hu, K.; Yu, Y.; Rotenberg, S. A.; Amatore, C.; Mirkin, M. V. Direct Electrochemical Measurements of Reactive Oxygen and Nitrogen Species in Nontransformed and Metastatic Human Breast Cells. J. Am. Chem. Soc. 2017, 139 (37), 1305513062. https://doi.org/10.1021/jacs.7b06476.

(40) Erofeev, A.; Gorelkin, P.; Garanina, A.; Alova, A.; Efremova, M.; Vorobyeva, N.; Edwards, C.; Korchev, Y.; Majouga, A. Novel Method for Rapid Toxicity Screening of Magnetic Nanoparticles. Sci. Rep. 2018, 8 (1), 7462. https://doi.org/10.1038/s41598-018-25852-4.

(41) Zhang, X.; Hatamie, A.; Ewing, A. G. Nanoelectrochemical Analysis inside a Single Living Cell. Current Opinion in Electrochemistry. Elsevier B.V. August 1, 2020, pp 94-101. https://doi.org/10.1016/j.coelec.2020.05.008.

(42) Zhang, Y.; Clausmeyer, J.; Babakinejad, B.; López Córdoba, A. Ali, T.; Shevchuk, A.; Takahashi, Y.; Novak, P.; Edwards, C.; Lab, M.; Gopal, S.; Chiappini, C.; Anand, U.; Magnani, L.; Coombes, R. C.; Gorelik, J.; Matsue, T.; Schuhmann, W.; Klenerman, D.; Sviderskaya, E. V.; Korchev, Y. Spearhead Nanometric FieldEffect Transistor Sensors for Single-Cell Analysis. ACS Nano 2016, $\quad 10 \quad 3214-3221$. https://doi.org/10.1021/acsnano.5b05211.

(43) Yang, C.; Hu, K.; Wang, D.; Zubi, Y.; Lee, S. T.; Puthongkham, P.; Mirkin, M. V.; Venton, B. J. Cavity Carbon-Nanopipette Electrodes for Dopamine Detection. Anal. Chem. 2019, 91 (7), 4618-4624.

https://doi.org/10.1021/acs.analchem.8b05885.

(44) Sun, P.; Laforge, F. O.; Abeyweera, T. P.; Rotenberg, S. A. Carpino, J.; Mirkin, M.V. Nanoelectrochemistry of Mammalian Cells. Proc. Natl. Acad. Sci. 2008, 105 (2), 443-448. https://doi.org/10.1073/pnas.0711075105.

(45) Jin, S.; Muhammad, N.; Sun, Y.; Tan, Y.; Yuan, H.; Song, D.; Guo, Z.; Wang, X. Multispecific Platinum(IV) Complex Deters Breast Cancer via Interposing Inflammation and Immunosuppression as an Inhibitor of COX-2 and PD-L1. Angew. Chemie Int. Ed. 2020, 59 (51), 23313-23321. https://doi.org/10.1002/ANIE.202011273.

(46) Helmlinger, G.; Yuan, F.; Dellian, M.; Jain, R. K. Interstitial PH and PO2 Gradients in Solid Tumors in Vivo: High-Resolution Measurements Reveal a Lack of Correlation. Nat. Med. 1997, 3 (2), 177-182. https://doi.org/10.1038/nm0297-177.

(47) Berners-Price, S. J.; Appleton, T. G. The Chemistry of Cisplatin in Aqueous Solution. In Platinum-Based Drugs in Cancer Therapy; Kelland, L. R., Farrell, N. P., Eds.; Humana Press: Totowa, NJ, 2000; pp 3-35. https://doi.org/10.1007/978-159259-012-4_1.

(48) Krasnovskaya, 0.; Spector, D.; Erofeev, A.; Gorelkin, P.; Akasov, R.; Skvortsov, D.; Trigub, A.; Vlasova, K.; Semkina, A.; Zyk, N.; Beloglazkina, E.; Majouga, A. Alternative Mechanism of Action of the DNP PtIV Prodrug: Intracellular Cisplatin Release and the Mitochondria-Mediated Apoptotic Pathway. Dalt. Trans. 2021, 50 (23), 7922-7927. https://doi.org/10.1039/D1DT00898F.

(49) Zhang, J. Z.; Bryce, N. S.; Lanzirotti, A.; Chen, C. K. J.; Paterson, D.; de Jonge, M. D.; Howard, D. L.; Hambley, T. W. Getting to the Core of Platinum Drug Bio-Distributions: The Penetration of Anti-Cancer Platinum Complexes into Spheroid Tumour Models. Metallomics 2012, 4 (11), 1209 https://doi.org/10.1039/c2mt20168b.

(50) Naumenko, V.; Jenne, C.; Mahoney, D. J. Intravital Microscopy for Imaging the Tumor Microenvironment in Live Mice; Ursini-Siegel, J., Beauchemin, N., Eds.; Springer New York: New York, NY, 2016; pp 217-230. https://doi.org/10.1007/978-1-4939-3801-8_16. 


\section{Graphical abstract}
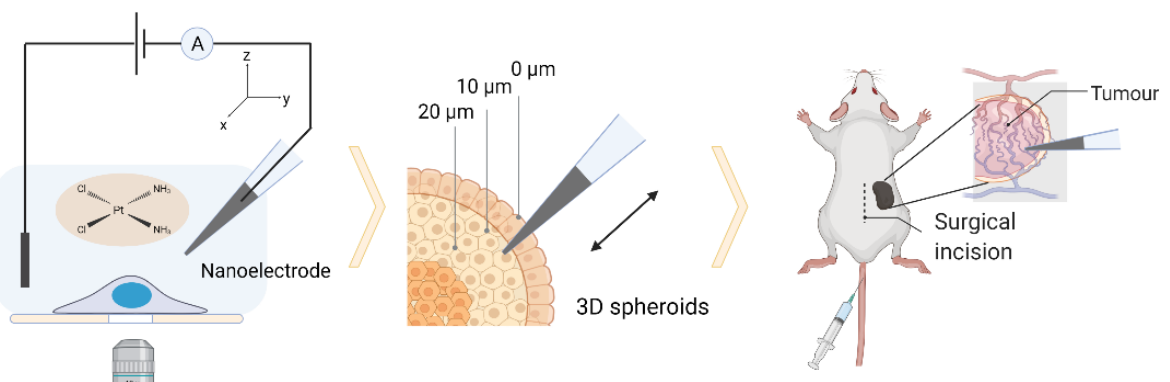

$40 \times$ 